\title{
The Astonishing Conclusion of the Attribution Debate on the Law of Comparative Advantage
}

\author{
Author: Jorge Morales Meoqui ${ }^{1}$
}

Preprint, February 2023

\begin{abstract}
The law of comparative advantage should not be attributed to anyone. This astonishing conclusion to the longstanding attribution debate on the law of comparative advantage comes from the recent demystification of David Ricardo's famous numerical example in chapter 7 of the Principles. It debunked the conventional narrative that his "four magic numbers" were the first proof of this law by showing that Ricardo chose them according to a different rule for specialization. Likewise, as this article shows, there is no hint of the law of comparative advantage in the writings of John Stuart Mill, James Mill and Robert Torrens. The belief in the existence of this alleged law grew out of the confusion created by J. S. Mill's misreading of the purpose, content and implications of Ricardo's numerical example. In truth, the law of comparative advantage is nothing more than a mythological construct, so no one deserves credit for it.
\end{abstract}

Keywords: law of comparative advantage, David Ricardo, Robert Torrens, James Mill, John Stuart Mill, classical rule for specialization

JEL-Codes: B12, B17, F10

Preprint DOI: 10.31219/osf.io/uwdbk

${ }^{1}$ Independent researcher. ORCID ID 0000-0002-4825-9666

E-mail: jorgemorales3@gmail.com

homepage: https://jorgemoralesmeoqui.academia.edu 


\section{Introduction}

It is better to debate a question without settling it than to settle a question without debating it.

Joseph Joubert

Joseph Joubert's aphorism is perhaps one of the few positive things that can be said about the current state of the attribution debate on the law of comparative advantage. The longstanding controversy over who should be credited with the earliest formulation of this alleged economic law arose in the first half of the 19th century and continues to this day. ${ }^{2}$ While most scholars have attributed it to David Ricardo, some have argued that Robert Torrens' Essay on the External Corn Trade (1815) already contained a satisfactory formulation of this law. ${ }^{3}$ On the other hand, John Aldrich (2004, 378-380) claimed that Torrens, Ricardo, James Mill and John Stuart Mill all contributed to the discovery of comparative advantage through a sequence of insights and arguments. Aldrich further argued that Ricardo did not appreciate that there was a principle worth developing. It was his close friend and collaborator James Mill who gave comparative advantage due emphasis, and John Stuart Mill who provided the appropriate setting for comparative advantage. Lastly, Denis P. O'Brien (2004, 211), Lars Magnussen (2004, 30-31), Istvan Hont $(2005,68)$ and Farhad Rassekh $(2015)$ claimed that Adam Smith already anticipated the theory of comparative advantage in the Wealth of Nations.

Likewise, there were also rather curious contributions to the attribution debate. For example, William O. Thweatt (1976) accused Ricardo of taking the law of comparative advantage from his close friend and collaborator James Mill. In contrast, Murray C. Kemp and Masayuki Osaka (2006) suggested in a footnote that Ricardo took it from Torrens, calling it the Torrens-Ricardo Principle of Comparative Advantage. In an attempt to reconcile all the conflicting claims, Leonard Gomes (1987) argued that comparative advantage was a case of multiple discovery, so the merit should be shared among several individuals.

\footnotetext{
${ }^{2}$ See Michael Gaul (2021) and Gilbert Faccarello (2022) for the most recent takes on who should be credited with the law of comparative advantage.

${ }^{3}$ See, for example, Emanuel Leser (1881, 82-83), Edwin R. Seligman (1903, 344; 1911), John S. Chipman $(1965,482)$ and Samuel Hollander $(1979,461)$. Jacob Viner had an ambiguous position in the attribution debate, as evidenced in the following statement: "Torrens clearly preceded Ricardo in publishing a fairly satisfactory formulation of the doctrine. It is unquestionable, however, that Ricardo is entitled to the credit for first giving due emphasis to the doctrine, for first placing it in an appropriate setting, and for obtaining general acceptance of it by economists" (Viner 1937, 442).
} 
As if this authorship kerfuffle $e^{4}$ was not chaotic enough, several scholars claimed that two anonymous pamphlets published in 1814 and 1818 also contained statements of the law of comparative advantage. Giancarlo de Vivo, the editor of the Collected Works of Robert Torrens (2000), asserted that on pages 7 to 10 of the pamphlet Considerations on the Importation of Foreign Corn (1814), there is a better formulation of the law of comparative advantage than in Torrens' essay (de Vivo 2010, 99-101). Martin Grančay \& Nóra Grančay (2015) and Andrea Maneschi (2017) recently echoed this claim. Arnold Plant (1933) and John Pullen (2006), on the other hand, affirmed that a remarkably clear statement of the law of comparative advantage is also to be found in the anonymous pamphlet titled $A$ Letter on the True Principles of Advantageous Exportation (1818).

In view of this "confused tangle of claims of priority, error, incompleteness, and attribution" (Ruffin 2002, 727-728), it seems rather unlikely that a generally accepted conclusion could ever emerge from the attribution debate on the law of comparative advantage. Any further attempt to revisit this topic seems doomed unless something very significant has happened that turns the entire debate upside down. This is arguably the case with the thorough demystification of Ricardo's famous numerical example put forward in two recently published articles (Morales Meoqui 2021 and 2023). Let's briefly resume the relevant insights in these articles for the attribution debate.

First, it is necessary to remember that the four numbers featuring an exchange of English cloth and Portuguese wine in chapter seven of the Principles have been the sole basis for attributing the law of comparative advantage to Ricardo. He claimed in the numerical example that it would be advantageous for Portugal to import some unspecified amount of cloth made by 100 Englishmen working for a year, although the cloth could have been produced locally with the labour of only 90 men (Vol. 1, 135). ${ }^{5}$ From his indication that the making of the cloth required less quantity of labour in Portugal than in England, scholars have generally inferred that the Portuguese cloth had to have a lower cost of production than the English cloth. Consequently, they interpreted the numerical example as an ingenious proof for the counterintuitive proposition that importing a commodity that would have cost less to produce locally might be beneficial. This proposition is said to have refuted the theory of absolute advantage in the cost of production, commonly misattributed to Adam Smith.

In refutation of the above interpretation of Ricardo's numerical example, the two papers (Morales Meoqui 2021 and 2023) proved that the Portuguese cloth had a higher cost of

\footnotetext{
${ }^{4}$ I borrowed this term from the presentation by economic historian Douglas A. Irwin at the Munich conference "Ricardo@200" commemorating the bicentenary of the publication of the four numbers on May 5th, 2017.

${ }^{5}$ Throughout this paper, all direct quotations of Ricardo are extracted from The Works and Correspondence of David Ricardo, Volume I to XI, 1951-1973, edited by Piero Sraffa. I will refer to them usually by indicating the volume and page numbers only.
} 
production than the English cloth. That is why the latter could be sold in the Portuguese market. Furthermore, the proper understanding of Ricardo's theory of value shows that he applied the same rule in the numerical example and elsewhere in the Principles as Smith in the Wealth of Nations. This rule, dubbed the classical rule for specialization, stipulates that one should acquire commodities abroad whenever they are offered more cheaply than what their local production would cost. A negative formulation of this rule would be that one should not attempt to make a commodity that costs less to buy. Ricardo believed that the costs of production of two bundles of commodities produced in the same country are approximately proportional to the quantities of labour embodied in them (Vol. 2, 35; Vol. 8, 279). Therefore, when he compared the quantities of labour required to produce the cloth and wine in England, he simply compared the cost of buying the wine with the cost of producing it locally. He then made the same comparison for Portugal in the next paragraph. Consequently, the four numbers must be interpreted as an application and not as a refutation of the classical rule for specialization.

Likewise, the most recent paper (Morales Meoqui 2023) rejected the common claim that Ricardo meant to prove with the numerical example that a less productive economy could participate in international trade but could not undersell a wealthier country in the production of every commodity. Instead, it argued that the sole purpose of the four numbers was to illustrate the proposition that the relative value of commodities made in different countries is not determined by the respective quantities of labour devoted to the production of each, as it would be if both commodities were manufactured in the same country (Vol. 1, 134-135).

These findings completely shake up the ongoing attribution debate on the law of comparative advantage. They reveal that the hitherto attribution of this alleged law to Ricardo resulted from an erroneous interpretation of the numerical example in the Principles. Likewise, they also refute the recent claim that traces of the law of comparative advantage were already present in the Wealth of Nations.

Against this background, the present article aims to re-evaluate whether there are statements of the law of comparative advantage in the writings of Robert Torrens, James Mill, and John Stuart Mill. The surprising result of this inquiry is that there are none. On the contrary, they all used the classical rule for specialization without exception. Thus, the main contribution of this paper is the proof that the law of comparative advantage cannot be attributed to any of the candidates usually mentioned in the attribution debate.

The paper is structured as follows. After this introduction, section two critically asserts the role of John Stuart Mill in popularising the misreading of Ricardo's numerical example. It is followed by a reappraisal of the alleged contribution of James Mill to the theory of comparative advantage in section three. The fourth and last section before the conclusions offers a re-examination of Torrens' alleged 1815 statement of the law of comparative advantage. 


\section{John Stuart Mill as the originator of the attribution kerfuffle}

Since the second half of the 19th century, the law of comparative advantage has been the economists' preferred argument for free trade. However, this was not the case for the first three decades after Ricardo's Principles was published. For example, there is not a single reference to the law of comparative advantage in Cheryl Schonhardt-Bailey's detailed book about the repeal of the Corn Laws (Schonhardt-Bailey 2006). It seems that no English writer on political economy even bothered to mention this law during the debates on the most contested trade-policy issue in England between 1815 and 1846.

There is a simple explanation for this glaring absence. Only two years before the repeal of the Corn Laws, J. S. Mill finally managed to publish his essay Of the Laws of Interchange Between Nations; and the Distribution of the Gains of Commerce Among Countries of the Commercial World (1844). This essay is said to contain the first complete formulation of the law of comparative advantage (Grančay and Szikorova 2013). Four years later, J. S. Mill reproduced the content of his essay with some additions and omissions in chapter XVIII of his book Principles of Political Economy with some of their Applications to Social Philosophy ([1848] 1965). According to Ruffin (2002, 742), "it was J. S. Mill who gave the analysis of comparative advantage the form that became an engine of analysis for generations to come and the starting point for all further developments in trade theory."

So it is safe to say that J. S. Mill played a paramount role in creating the myth that there is such a thing as Ricardo's law of comparative advantage. Indeed, this myth gradually grew out of J. S. Mill's misreading of the purpose, content and implications of Ricardo's four numbers in his Essay (1844) and Principles (1848). He claimed there, among other erroneous assertions, that the cost of production did not regulate the relative value of commodities produced in different countries and that Ricardo had allegedly shown that "it is not a difference in the absolute cost of production, which determines the interchange, but a difference in the comparative cost" (Mill [1848] 1965, Vol. III, 589).

As already explained in greater detail on previous occasions (Morales Meoqui 2021, 444446; and 2020), the above claims were made with a different notion of the cost of production in mind than the one used by Ricardo in the Principles. J. S. Mill's notion of the cost of production did not include the ordinary rate of profits (Mill [1848] 1965, 471). Ricardo, on the other hand, repeatedly and unequivocally asserted that the ordinary rate of profits was an integral part of the cost of production (Vol. 1, 47; Vol. 2, 369; Vol. 4, 25).

In retrospect, I find it quite puzzling that so many prestigious scholars have overlooked the fact that J. S. Mill used a different notion of cost of production than Ricardo. It is perhaps the clearest indication of how poorly Ricardo's value theory has been understood in academia over the past 200 years. Apparently few knew that for Ricardo the cost of production was just another name for the natural price, which he also referred to as the necessary price (Vol. 1, 119-120, 383; Vol. 2, 34-35, 46-47, 219). Otherwise, scholars would have noticed from the 
very beginning that J. S. Mill openly contradicted Ricardo on the role of the cost of production in regulating exchange value in international trade. While the former claimed that the cost of production did not regulate the relative value of commodities produced in different countries, Ricardo stated in the Principles that "it is the natural price of commodities in the exporting country, which ultimately regulates the prices at which they shall be sold, if they are not the objects of monopoly, in the importing country" (Vol. 1, 375).

Perhaps many scholars took J. S. Mill's interpretation of the Ricardian theory at face value because of his biography. John Stuart's father, James Mill, was a close friend and disciple of Ricardo on the subject of political economy (Vol. 9, 391). He taught his son the basics of this science from a very young age. However, proximity to the primary source does not preclude the possibility of misunderstandings and disagreements. It may be worth recalling at this point that Ricardo dedicated his very last letter to James Mill, on September 5, 1823, in its entirety to commenting on his disagreement with an article written by J. S. Mill on the measure of value (Vol. 9, 385-387).

J. S. Mill was undoubtedly the most influential mystifier of Ricardo's numerical example. However, his erroneous statements about it in the two writings should never have been interpreted as proposing or approving a new law, principle or rule for international specialization since he stated in his Principles the following:

Some things it is physically impossible to produce, except in particular circumstances of heat, soil, water, or atmosphere. But there are many things which, though they could be produced at home without difficulty, and in any quantity, are yet imported from a distance. The explanation which would be popularly given of this would be, that it is cheaper to import than to produce them: and this is the true reason (Mill [1848] 1965, Vol. III, 587).

As he further clarified in the next paragraph, what he meant to explain is why a "thing may sometimes be sold cheapest, by being produced in some other place than that at which it can be produced with the smallest amount of labour and abstinence" (Mill [1848] 1965, Vol. III, 587). Therefore, one has to conclude that J. S. Mill, following Smith and Ricardo, consistently adhered to the classical rule for specialization.

The fact that J. S. Mill learned the fundamentals of political economy from his father suggests the necessity of examining the latter's role concerning the misinterpretation of Ricardo's numerical example. In the next section, I will analyze the passages in James Mill's writings most relevant to the attribution debate on the law of comparative advantage to determine whether he laid the foundation for his son's misinterpretation of Ricardo's famous four numbers. 


\section{James Mill's defective popularisation of Ricardo's numerical example}

James Mill wrote his Elements of Political Economy ([1821] 1826) as a schoolbook on political economy with the clear objective of popularizing Ricardo's doctrines among those unfamiliar with the basics of the science. Consequently, Mill explicitly ruled out having made any original discoveries in the introduction of the Elements (Mill [1821] 1826, iii-iv). These facts alone should have been reason enough not to consider him a potential discoverer of the law of comparative advantage. On top of this, a few years earlier, Mill praised Ricardo in a letter commenting on the manuscript of the Principles for fully proving the novel proposition that "it may be good for a country to import commodities from a country where the production of those same commodities costs more, than it would cost at home" (Vol. 7, 99).

All this was already known when Thweatt (1976) claimed that Ricardo must have taken the law of comparative advantage from James Mill. Three decades later, Murray N. Rothbard (1996) and Mark Blaug $(1997,132)$ echoed this spurious accusation against Ricardo. Why did these three scholars make this claim, despite clear evidence to the contrary? Because since the mainstream interpretation of the famous numerical example bears so little relationship and compatibility with what is written in the Principles, they thought that someone other than Ricardo had to have formulated it. The only plausible candidate for such an unlikely action was James Mill, who reviewed and corrected the book's manuscript.

The thorough demystification of Ricardo's numerical example puts an end to this unfounded speculation. When interpreted correctly, the four numbers and the explanations in the surrounding paragraphs fit perfectly with Ricardo's theories of value and international trade set out in the Principles. This further refutes the unfounded claim that he took something from James Mill. Regardless, it seems worthwhile taking a closer look at two writings by the latter that are most relevant to the attribution debate on the law of comparative advantage, as they now appear in a different light.

James Mill's article Colony ${ }^{6}$ for the Encyclopaedia Britannica is said to contain the first popularisation attempt of Ricardo's insights related to the canonical numerical example in the Principles. It can be found in the following two paragraphs of the article:

Not only does a variation in the state of wages and profits give no obstruction to foreign trade, a variation even in the cost of production gives no obstruction. A nation exports to another country, not because it can make cheaper than another country; for it may continue to export, though it can make nothing cheaper. It exports, because it can, by that means, get something cheaper from another country, than it can make it at home. But how can it, in that case, get it cheaper than it can make it at home? By exchanging for it something which costs it less labour than making it at home would cost it. No matter how much of that commodity it is necessary to give in exchange. So long as what it does

\footnotetext{
${ }^{6}$ I'm indebted to Taichi Tabuchi for drawing my attention to James Mill's article. It was written in late 1817 and first published in February 1818.
} 
give is produced by less labour, than the commodity which it gets for it could be produced by at home, it is the interest of the country to export.

Suppose that the same quantity of corn which is produced in England by the labour of 100 men, England can purchase in Poland with a quantity of cotton goods which she has produced with the labour of 90 men; it is evident that England is benefited by importing the corn and exporting the cotton goods, whatever may be the price of the cotton goods in Poland, or the cost of producing them. Suppose that the cotton goods could be produced in Poland with the labour of 85 men, that is, less than they are supposed to be produced with in England. Even that would not hinder the trade between them. Suppose that the same quantity of corn, which is raised in England with the labour of 100 men, is raised in Poland with the labour of 80; in that case, it is plain, that Poland can get with 80 men's labour, through the medium of her corn, the same quantity of cotton goods which would cost her the labour of 85 men, if she was to make them at home. Both nations, therefore, profit by this transaction; England to the extent of 10 men's labour, Poland to the extent of 5 men's labour; and the transaction, in a state of freedom, will be sure to take place between them, though England is less favourably situated than Poland with regard to both articles of production (Mill [1818] 1825, 26-27).

The corresponding numbers are represented in the two tables beneath to facilitate the comparison between the numerical examples in Colony and the Principles. They indicate the number of men necessary to produce some unspecified amounts of commodities traded between two countries.

\begin{tabular}{|c|c|c|}
\hline & cloth & wine \\
\hline England & 100 men & 120 men \\
\hline Portugal & 90 men & 80 men \\
\hline
\end{tabular}

Table 1: Ricardo's numerical example in Principles

\begin{tabular}{|r|c|c|}
\hline & cotton goods & corn \\
\hline England & 90 men & 100 men \\
\hline Poland & 85 men & 80 men \\
\hline
\end{tabular}

Table 2: James Mill's numerical example in Colony

The numerical example in Colony differs from Ricardo's in the countries selected - Poland instead of Portugal -the commodities traded - corn instead of wine -and the specific numbers corresponding to each country. Besides these superficial differences, though, the numerical example in Colony replicated the core features of the canonical numerical example in the Principles. Fewer men are required in Poland compared to England to produce the unspecified amounts of cotton goods and corn traded between the two countries. Notwithstanding, both nations benefit from this exchange, as each of them would have 
required more men to produce the imported good internally than the good exported. In other words, the English cotton goods and the Polish corn would be cheaper to import than to produce locally, as the classical rule for specialization stipulates.

At first glance, Mill seems to have understood Ricardo's numerical example quite well. In correspondence with the latter, Mill also formulated a numerical example in which the two bundles of goods traded required different quantities of labour for their production. This correspondence is by no means accidental. As I have shown on a previous occasion (Morales Meoqui 2017, 39-40), it is not possible to find a combination of numbers that proves that the exchange of English cotton goods and Polish corn is mutually beneficial if the amounts exchanged have to have the same quantity of labor, and one of the two countries requires less labor for making both goods.

However, one critical element is missing from the numerical example in Colony. Unlike Ricardo in the Principles, Mill does not explain at all why the product of the labour of 90 Englishmen could be exchanged for that of 80 Polish men. Consequently, he does not mention the difference in the ordinary rates of profit between the two countries, although it is the crucial element for the explanation of the lower cost of production of the English cotton goods. This assertation requires a brief proof.

Since the English cotton goods and the Polish corn were exchanged in barter trade, they must have the same value, natural price or cost of production. Moreover, as making cotton goods in Poland would require more labour ( 85 men) than making corn ( 80 men), the cost of production of Polish cotton goods has to be higher than that of corn. By applying transitivity, one can conclude that the cotton goods made in Poland have to have a higher cost of production than the cotton goods made in England, irrespective of the fact that the Polish cotton goods could have been produced with less quantity of labour.

In Algebra language, one can state this proof in a single line. The variables $C O_{P O L}, C G_{E N G}$ and $C G_{P O L}$ represent the costs of production of Polish corn, English cotton goods and Polish cotton goods, respectively:

$$
\text { Since } C O_{P O L}=C G_{E N G} \text { and } C G_{P O L}>C O_{P O L} \Rightarrow C G_{P O L}>C G_{E N G}
$$

At first sight, the proof that the English cotton goods had a lower cost of production than the cotton goods made in Poland seems to contradict Mill's claim that a country might export, although it can make nothing cheaper (Mill [1818] 1825, 26). But Mill's claim is perfectly compatible with this proof if he was referring to the cost price of commodities, which does not include ordinary profits. A country where the ordinary rate of profit is $20 \%$ might import a commodity, although it could produce it locally at a $5 \%$ lower cost price than the exporting country. If the ordinary rate of profit in the exporting country is only $10 \%$, the natural price of the foreign commodity would still be lower than the natural price of the local product. 
Therefore, Mill's statement in Colony was perhaps unprecise and potentially misleading but not necessarily wrong.

Against this background, Mill's decision not to explain why the product of the labour of 90 men in England could be exchanged for that of 80 men in Poland must be viewed as a significant departure from the numerical example in the Principles. He omitted nothing less than the main proposition that Ricardo wanted to illustrate with the famous four numbers.

Two other differences between the numerical examples in Colony and the Principles are also worth mentioning. Unlike Ricardo, Mill specified the gains from trade as the number of men each country saves in the exchange: 10 men in the case of England and 5 men for Poland. This calculation might have misled J. S. Mill and probably Sraffa (1930) into believing that Ricardo's numerical example was about the proper measurement of the gains from trade. Moreover, Mill indicated that England was the less favourably situated country. This indication might have contributed to the myth about Portugal's alleged productivity advantage over England. Therefore, Mill's article in Colony could well be the origin of the gains-from-trade narrative and the productivity narrative currently associated with Ricardo's numerical example. A previous article already debunked both narratives (Morales Meoqui, 2023).

Mill's second popularisation attempt of Ricardo's insight can be found in Chapter 3: "Interchange", Section IV: "Occasions on which it is the Interest of Nations to exchange Commodities with one another" of the Elements (Mill [1821] 1826, 118-125). He made changes to this section in the second and third editions of the book, which proves that he struggled to find a satisfactory formulation. I won't go here into the details of these alterations. Instead, I will focus on a passage that remained unchanged throughout the three editions of the Elements, namely the following:

(1) To produce exchange, therefore, there must be two countries, and two commodities.

(2) When both countries can produce both commodities, it is not greater absolute, but greater relative, facility that induces one of them to confine itself to the production of one of the commodities, and to import the other.

(3) When a country can either import a commodity, or produce it at home, it compares the cost of producing at home with the cost of procuring from abroad; if the latter cost is less than the first, it imports.

(4) The cost at which a country can import from abroad depends, not upon the cost at which the foreign country produces the commodity, but upon what the commodity costs which it sends in exchange, compared with the cost which it must be at to produce the commodity in question, if it did not import it.

(5) If a quarter of corn is produced in England with 50 days' labour, it may be equally her interest to import corn from Poland, whether it requires, in Poland, 50 days' labour, or 60 , or 40 , or any other number. Her only consideration is, whether the commodity with which she can import a quarter costs her less than 50 days' labour (Mill [1821] 1826, 123-124). 
I have numbered the five paragraphs for ease of reference. James Mill's contraposition of greater relative facility versus greater absolute facility in paragraph (2) is sometimes interpreted as an equivalent formulation to J. S. Mill's contraposition of comparative versus absolute advantage in the cost of production. The two contrapositions, however, are not equivalent since James Mill explicitly indicated that by superior facilities, he meant "the power of producing the same effect with less labour. The conclusion, too, will be the same, whether we suppose the labour to be more or less highly paid." (Mill [1821] 1826, 119). Thus, the higher (or lower) quantity of labor required for the production of the Polish corn did not imply that its cost of production was higher (or lower) than that of the English corn. Only the internal comparison of quantities-of-labor requirements mattered, as James Mill clarifies in paragraph (5).

In paragraphs (3) and (4), James Mill applied the classical rule for specialization. This rule also appears in Colony. There he stated that "it is a point established in the science of Political Economy, that it is not good policy to confine consumption to any sort of home manufacture, when it can be purchased more cheaply abroad" (Mill [1818] 1825, 23). The imported good can only be purchased cheaper in significant quantities or for a prolonged time, though, when its natural or necessary price (= cost of production) in the exporting country is lower than in the importing country. ${ }^{7}$

In summary, there is no trace of the law of comparative advantage in James Mill's attempts to popularize Ricardo's canonical numerical example in Colony and Elements. He adhered in both writings to the classical rule for specialization.

The present and previous sections have discarded James and John Stuart Mill, respectively, as potential proponents of the law of comparative advantage. This leaves Torrens as the only plausible proponent. His alleged statement of the law of comparative advantage will be analyzed in detail in the next section.

\footnotetext{
${ }^{7}$ Smith was unambiguous in this respect, as he stated in the Wealth of Nations that though the natural price "is not always the lowest at which a dealer may sometimes sell his goods, it is the lowest at which he is likely to sell them for any considerable time" (WN I.vii.6, 73). This core tenet of classical political economy certainly also applies to Ricardo's four numbers, as can be seen in the following statement in the Principles: "Thus, cloth cannot be imported into Portugal, unless it sell there for more gold than it cost in the country from which it was imported; and wine cannot be imported into England, unless it will sell for more there than it cost in Portugal. If the trade were purely a trade of barter, it could only continue whilst England could make cloth so cheap as to obtain a greater quantity of wine with a given quantity of labour, by manufacturing cloth than by growing vines; and also whilst the industry of Portugal were attended by the reverse effects" (Vol. 1, 137).
} 


\section{A reassessment of Torrens' alleged 1815 statement of the law of comparative advantage}

In 1911 Edwin R. Seligman (1911) and Jacob H. Hollander (1911) had a notorious debate in the pages of The Economic Journal over whether the law of comparative advantage should be attributed to Torrens or Ricardo. More than a century later, the debate about this topic continues. Ruffin (2002) conceded that Torrens' Essay on the External Corn Trade (1815) contained a six-word phrase that fits the law of comparative advantage. Notwithstanding, he rejected the attribution of this law to Torrens by highlighting some shortcomings of the 1815 statement (Ruffin 2002, 731-735). Ruffin mentioned, among other things, the lack of a comparison of cost ratios. ${ }^{8}$ Likewise, he portrayed Torrens in a follow-up paper as the foremost advocate of the absolute cost advantage theory of trade (Ruffin 2005, 715-718), with the explicit goal of disqualifying him as the first proponent of the law of comparative advantage.

Ruffin's arguments persuaded Douglas Irwin and Andrea Maneschi to switch sides and join the ranks of the Ricardo supporters. Both Irwin (1996) and Maneschi (1998) had previously discussed without disputing Chipman's assessment $(1965,482)$ that the credit for the discovery of comparative advantage should go to Torrens. Likewise, Ruffin's rejection of Torrens' claim for the discovery of comparative advantage based on his alleged endorsement of the theory of absolute cost advantage was recently echoed by Gaul (2021).

In retrospect, though, it can be seen that Ruffin's main arguments against attributing the law of comparative advantage to Torrens have not aged well. First, Christian Gehrke (2015) thoroughly debunked Ruffin's reconstruction of Ricardo's discovery process of the law of comparative advantage. Moreover, the absence of a comparison of cost ratios in Torrens' statement has to be viewed now as an argument in his favor rather than against him because this comparison might recommend an exchange that Ricardo would have considered unfavorable (Morales Meoqui 2017). Lastly, the refutation of the contraposition of absolute and comparative advantage in the cost of production (Morales Meoqui 2021) rendered the argument obsolete that Torrens could not be credited with the latter because he adhered to the former.

However, the above should not be interpreted as an endorsement of the view that the law of comparative advantage should be attributed to Torrens. To the contrary, I believe that his alleged anticipation of the law of comparative advantage is a myth, but for different reasons than the ones indicated by Ruffin. First, it is essential to recognize that Torrens used the

\footnotetext{
${ }^{8}$ Ruffin refers approvingly to the following quote from Lionel Robbins $(1958,23)$ : "As pure analysis, it still lacks the final emphasis upon the comparison of ratios which is the ultimate essence of the principle."
} 
classical rule for specialization in several passages of the Essay. ${ }^{9}$ Perhaps his most precise formulation of this rule is contained in the following statement:

In countries where the natural, or what may be called the growing price of corn, is so high as to cause, in average years, a part of their consumption to be brought from other countries, an unrestricted importation trade is necessary to prevent a ruinous fluctuation in the markets. For the expense of carriage on an article so bulky as corn, affords so great a protection to the home grower, that corn will not be permanently imported, except into a country where its natural price is very considerably above the level of other countries (...). Exportation can take place only from places where articles are cheap, into those where they are dear (Torrens 1815, 45-46).

The only passage in the Essay that scholars have interpreted as a statement of the law of comparative advantage is a six-word phrase on page 264. But did the six words convey a new law or principle that contradicts or refutes the classical rule for specialization? I will reproduce the entire passage below to understand better the context in which the phrase appears. It states as follows:

It is abundantly evident, that where free intercourse is permitted, no country possessing any articles, which can profitably be sent abroad in exchange for corn, will cultivate lands very much inferior to those under cultivation in adjacent countries. When, in the progress of wealth and population, tillage has been extended over all the fertile districts of a country, and when the expense of raising grain from soils of inferior quality, would exceed the cost of bringing it from abroad, then, unless some arbitrary legislative interference should disturb the natural course of events, subsistence will be imported.

Even long before the lands of superior quality have been brought under the plough, a country, though exempt from all legislative interference with the direction of its industry, may yet be naturally led to import a part of her consumption, rather than to grow an independent supply of corn. To illustrate this, let us suppose, that there are, in England, unreclaimed districts, from which corn might be raised at as small an expense of labour and capital, as from the fertile plains of Poland. This being the case, and all other things the same, the person who should cultivate our unreclaimed districts, could afford to sell his produce at as cheap a rate, as the cultivator of Poland; and it seems natural to conclude, that if industry were left to take its most profitable direction, capital would be employed in raising corn at home, rather than in bringing it from Poland at an equal prime cost, and at a much greater expense of carriage. But this conclusion, however obvious and natural it may, at first sight, appear, might, on a closer examination, be found entirely erroneous. If England should have acquired such a degree of skill in manufactures, that, with any given portion of her capital, she could prepare a quantity of cloth, for which the Polish cultivator would give a greater quantity of corn, than she could, with the same portion of capital, raise from her own soil, then, tracts of her territory, though they should be equal, nay, even though they should be superior, to the lands in Poland, will be neglected; and a part of her supply of corn will be imported from that country. For, though the capital employed in cultivating at home, might bring an excess of profit, over the capital employed in cultivating abroad, yet, under the supposition, the capital which should be employed in manufacturing, would obtain a still greater excess of profit; and

\footnotetext{
${ }^{9}$ See, for example, Torrens $(1815,47-48 ; 221-222 ; 266)$.
} 
this greater excess of profit would determine the direction of our industry (Torrens 1815, 262-265, bold added).

Torrens indicated in the first paragraph that a country would not cultivate land of inferior quality relative to those of neighbouring countries since the cost of producing corn from those soils would probably exceed the cost of acquiring it abroad. Of course, this statement only applies if the country has other articles to export and there are no trade barriers in place, as he explicitly recognized. Torrens further argued in the second paragraph that the country would import corn even if it had land of superior quality still available for production. To illustrate this, he presented an example featuring an exchange of cloth and corn between England and Poland. Although an English cultivator could produce the corn at an equal prime cost than a Polish cultivator, corn would be imported into England as long as the manufacturing of cloth renders there more profit than the cultivation of corn, because capital would naturally flow to the activity with the higher profitability.

Nothing in the above passage of the Essay hints at a new law or principle that contradicts the classical rule for specialization. Torrens explicitly refers there to prime costs, also known as variable costs. Prime costs include direct labor and material costs but no profits. They are not equivalent to Ricardo's concept of the cost of production, which always includes ordinary profits. Suppose the Polish cultivator could afford to sell the corn at a price below the cost of production of the English cultivator. In that case, the latter might well renounce to cultivate the land of superior quality in his home country. Torrens had already explained this in an earlier passage of the Essay:

If, in any country, the customary rate of profit upon commercial and manufacturing stock be fifteen per cent, while the rate of profit upon the stock which might be turned to the extension of tillage would amount only to ten per cent. it is evident that tillage cannot be extended, that tracts, which would afford the speculator a profit of only ten per cent. will remain unreclaimed, and that cultivation will be confined to such fertile districts as can yield to the capitalist the customary return (Torrens 1815, 49-50).

Thus, the six words in no way contradict the classical rule for specialization. Indeed, there should be no doubts that this was the rule that Torrens considered relevant for the importation of corn, since only a few paragraphs later, he posed the following rhetorical question: "Why is corn imported? For no assignable, no conceivable reason, except that it is found cheaper to import, than to grow" (Torrens 1815, 266).

But how is this finding compatible with Torrens' alleged claim of priority with regard to the law of comparative advantage ? $^{10}$ He formulated this claim in the preface of the 1826 edition of his Essay in the following terms:

${ }^{10}$ Giancarlo de Vivo, the editor of the Collected Works of Robert Torrens (2000), points out that Torrens made two different priority-claims: one regarding the advantages derived from trade in general based on The Economists Refuted, and another regarding comparative advantage in the preface of the 1826 edition of the External Corn Trade. De Vivo considers both claims far from 
In the earlier edition of the Essay on the Corn Trade, it was shown, the Author believes for the first time, that a permanently high scale of general prices, from whatever cause arising, cannot depress domestic industry by encouraging the importation of cheaper foreign articles; and that commodities, the cost of producing which is greater in foreign countries than at home, may, nevertheless, be imported, provided the comparative disadvantage of the foreign capitalist in producing the imported article, be less than the comparative advantage of the domestic capitalist in producing the articles exported in exchange. These principles Mr. Ricardo adopted into his very valuable work upon Political Economy and Taxation; and they form, in some measure, the ground-work of his chapters upon foreign trade, and of his doctrines on the influence of taxation upon the export and import of commodities (Torrens 1826, vii-viii, bold added).

Torrens made the above claim publicly three years after Ricardo's death in 1823 . It is uncertain whether he had already brought up the issue in his private correspondence with Ricardo. The latter recounted in a letter to Hutches Trower (Vol. 7, 179-180) that Torrens had written him to express disappointment for not being mentioned in the Principles and to claim merit as the original discoverer of some of the economic principles established in the book. Ricardo denied any intention of neglecting his merits and asserted to have convincingly argued in his reply to Torrens "that on all those points which I had as I thought for the first time brought forward, his published opinions were in fact in opposition to mine, and on those which he said we agreed upon and for which he claimed the merit of originality they were all to be found in Adam Smith or Malthus, and therefore neither of us could be called discoverers" (Vol. 7, 180).

Unfortunately, the correspondence between Torrens and Ricardo was lost, so it is impossible to know with certainty now whether the famous four numbers were part of their discussion. According to Ricardo, the altercation between him and Torrens was carried on without the least acrimony and ended with a complete restoration of cordiality. As a result, he added two references to Torrens' Essay in the second edition of the Principles (Vol. 1, 9697n. and 271n.). However, these references had nothing to do with the four numbers. Instead, one can find the following footnote on page 136 of the Principles:

It will appear then, that a country possessing very considerable advantages in machinery and skill, and which may therefore be enabled to manufacture commodities with much less labour than her neighbours, may, in return for such commodities, import a portion of the corn required for its consumption, even if its land were more fertile, and corn could be grown with less labour than in the country from which it was imported. Two men can both make shoes and hats, and one is superior to the other in both employments; but in making hats, he can only exceed his competitor by one-fifth or 20 per cent., and in making shoes he can excel him by one-third or 33 per cent.; - will it not be for the interest of both, that the superior man should employ himself exclusively in making shoes, and the inferior man in making hats? (Vol. 1, 136n.).

convincing and hardly reconcilable with Torrens' sweeping acknowledgements of Ricardo's priority on the theory of foreign trade. See Torrens (2000, Vol. II, xvii-xix; Vol. VI, xxii). 
Each of the two sentences in the footnote refers to a specific passage from the Wealth of Nations. The second sentence - which starts with "Two men can..."- is an apparent reference to Smith's tailor and shoemaker example, as Sraffa already pointed out. The first sentence is most certainly referring to the following passage of the Wealth of Nations:

The most opulent nations, indeed, generally excel all their neighbours in agriculture as well as in manufactures; but they are commonly more distinguished by their superiority in the latter than in the former. Their lands are in general better cultivated, and having more labour and expence bestowed upon them, produce more, in proportion to the extent and natural fertility of the ground. But this superiority of produce is seldom much more than in proportion to the superiority of labour and expence. In agriculture, the labour of the rich country is not always much more productive than that of the poor; or, at least, it is never so much more productive, as it commonly is in manufactures. The corn of the rich country, therefore, will not always, in the same degree of goodness, come cheaper to market than that of the poor (WN, I.i.4, 16).

Smith hinted there at the possibility that a rich country might import corn from a poorer country, although the former excels both in agriculture and manufacturing. He illustrates this by using the same commodities (corn and cloth) and countries (England and Poland) mentioned later by Torrens. So it's understandable why Ricardo felt no obligation to credit the latter for any insight related to the theory of international trade.

\section{Conclusions}

For decades, if not centuries, generations of scholars have hailed the law of comparative advantage as "one of the crown jewels of the economics profession" (Rodrik 1998, 3). Convinced of its scientific value, they have debated for almost two centuries whether Ricardo, Torrens, James Mill or John Stuart Mill should be credited for formulating this alleged economics law. In search for its earliest formulation, many believed to have found traces of the law of comparative advantage in a footnote written by Ricardo, in James Mill's Elements, in a six-word phrase written by Torrens, and, more recently, in the two anonymous pamphlets Considerations (1814) and Advantageous Exportation (1818).

However, in truth, the aforementioned claims were red herrings. Once one realizes that the law of comparative advantage is not a crown jewel but a fake gem, the scant, isolated, conflicting and inconclusive evidence for its alleged presence in the primary literature appears in a different light.

In two previous articles (Morales Meoqui 2021 and 2023), I already showed that Smith and Ricardo consistently used the classical rule for specialization throughout the Wealth of Nations and the Principles, respectively. The preceding sections of this paper revealed that Robert Torrens, James Mill and John Stuart Mill also applied this rule without exception. Consequently, none ot them can be charged with proposing an economic law that supposedly refuted the classical rule for specialization. The same can be said about the unknown authors 
of the two anonymous pamphlets mentioned above. A closer examination of these pamphlets would reveal that they only contain statements of the classical rule for specialization. However, such a task was beyond the scope of this paper. I will leave it to other scholars to verify this claim if they deem it necessary.

The main conclusions of the longest-running and chaotic attribution debate in the history of economic thought are as follows: Every economic thinker who has been credited with formulating the law of comparative advantage used only the very rule that this law supposedly refuted. Moreover, the law of comparative advantage is a mythological construct that emerged from a remarkable chain of overlooked misinterpretations. Whoever was the first link in this chain does not deserve any merit. The fable about the law of comparative advantage probably arose in the mind of a reader of J. S. Mill's essay and book. He made there the contraposition of absolute and comparative advantage in the cost of production based on a fundamental misinterpretation of Ricardo's value theory. Subsequent generations of scholars used this contraposition without ever realizing the error.

I am well aware that the aforementioned conclusions from the longstanding attribution debate on the law of comparative advantage are an unflattering outcome for the economics profession. It is indeed embarrassing when the very theory that many renowned economists have heralded as the pons asinorum of our field of knowledge is thoroughly disproved. But this unflattering outcome also has a silver lining: at least we don't have to debate the proper attribution of the law of comparative advantage for another century without ever coming to a conclusion.

\section{Acknowledgments}

I wish to thank Roy Ruffin, Farhad Rassekh and Giancarlo de Vivo for commenting on earlier versions of this paper. None of them is responsible for the remaining errors and omissions. 


\section{References}

Aldrich, John. 2004. The Discovery of Comparative Advantage. Journal of the History of Economic Thought, 26 (3): 379-399.

Allington, Nigel F. B. and Noel W. Thompson, eds. 2010. English, Irish and Subversives among the Dismal Scientists. Bingley: Emerald.

[Anonymous]. 1814. Considerations on the Importation of Foreign Corn. London: [s. n.].

Blaug, Mark. 1997. Economic Theory in Retrospect ( $5^{\text {th }}$ Edition). Cambridge: Cambridge University Press.

Chipman, John S. 1965. A Survey of the Theory of International Trade: Part 1, The Classical Theory. Econometrica, 33 (3): 477-519.

De Vivo, Giancarlo. 2010. Robert Torrens as a 'neglected economist'. In English, Irish and Subversives among the Dismal Scientists, eds. Nigel F. B. Allington and Noel W. Thompson. Bingley: Emerald, pp. 89-110.

Faccarello, Gilbert. 2022. "I profess to have made no discovery". James Mill on Comparative Advantage. The European Journal of the History of Economic Thought, 29 (1): 61-81.

Gaul, Michael. 2021. Robert Torrens' model of trade and growth: genesis and implications for the discovery of comparative advantage. The European Journal of the History of Economic Thought, 28 (2): 201-228.

Gehrke, Christian. 2015. Ricardo's Discovery of Comparative Advantage Revisited: A Critique of Ruffin's Account. The European Journal of the History of Economic Thought, 22 (5): 791-817.

Gehrke, Christian. 2017. Foreign trade, international values, and gains from trade. In Ricardo and International Trade, eds. Shigeyoshi Senga, Masatomi Fujimoto, and Taichi Tabuchi. London: Routledge, pp. 139-163.

Gomes, Leonard. 1987. Foreign Trade and the National Economy: Mercantilist and Classical Perspectives. New York: Palgrave Macmillan.

Grančay, Martin and Szikorova, Nóra. 2013. History of the Principle of Comparative Advantage Revisited: What makes a satisfactory definition? History of Economic Ideas, XXI (3): 43-68.

Grančay, Martin and Grančay, Nóra. 2015. Considerations on the Importation of Foreign Corn (1814) and the Principle of Comparative Advantage. History of Economics Review, 61 (1): 69-77.

Hollander, Jacob H. 1911. Ricardo and Torrens. The Economic Journal, 21 (83): 455-468.

Hollander, Samuel. 1979. The Economics of David Ricardo. London: Heinemann. 
Hont, Istvan. 2005. Jealousy of Trade: International Competition and the Nation-State in Historical Perspective. Cambridge, MA, and London: Harvard University Press.

Irwin, Douglas A. 1996. Against the Tide: An Intellectual History of Free Trade. Princeton (NJ): Princeton University Press.

Kemp, Murray C. and Okawa, Masayuki. 2006. The Torrens-Ricardo Principle of Comparative Advantage: an Extension. Review of International Economics, 14 (3): 466477.

Leser, Emanuel. 1881. Untersuchungen zur Geschichte der Nationalökonomie, Vol. I. Jena: Fischer.

Magnusson, Lars. 2004. The tradition of free trade. London: Routledge.

Maneschi, Andrea. 2017. David Ricardo's Trade Theory: Anticipations and Later Developments. In Ricardo and International Trade, eds. Shigeyoshi Senga, Masatomi Fujimoto, and Taichi Tabuchi. London: Routledge, pp. 33-47.

Maneschi, Andrea. 1998. Comparative Advantage in International Trade. Cheltenham: Edward Elgar Publishing Limited.

Mill, James. [1818] 1825. Colony. London: J. Innes. Available at: http://oll.libertyfund.org/titles/1765. Accessed on March 10, 2017.

Mill, James. [1821] 1826. Elements of Political Economy (3rd Edition). London: Baldwin, Cradock and Joy.

Mill, John Stuart. [1848] 1965. Principles of Political Economy with some of their Applications to Social Philosophy. Edited by John M. Robson. In The Collected Works of John Stuart Mill. Toronto: University of Toronto Press.

Mill, John Stuart. 1844. Essays on Some Unsettled Questions of Political Economy. London: Parker, John W.

Morales Meoqui, Jorge. (2023). The Demystification of David Ricardo's Famous Four Numbers. Journal of the History of Economic Thought, 1-20. doi:10.1017/S1053837222000256.

Morales Meoqui, Jorge. 2021. Overcoming Absolute and Comparative Advantage: A Reappraisal of the Relative Cheapness of Foreign Commodities as the Basis of International Trade. Journal of the History of Economic Thought, 43 (3): 433-449. doi:10.1017/S1053837220000401.

Morales Meoqui, Jorge. 2017. Ricardo's Numerical Example versus Ricardian Trade Model: A Comparison of Two Distinct Notions of Comparative Advantage. Economic Thought, 6 (1): 35-55. https://www.worldeconomicsassociation.org/files/journals/economicthought/WEA-ET6-1-MoralesMeoqui.pdf. 
O'Brien, Denis P. 2004. The Classical Economists Revisited. Princeton: Princeton University Press.

Plant, Arnold. 1933. A letter on the true principles of advantageous exportation, 1818. Economica, 13: 40-83.

Pullen, John. 2006. Did Ricardo Really Have a Law of Comparative Advantage? A Comparison of Ricardo's Version and the Modern Version. History of Economics Review, 44 (1): 5975.

Rassekh, Farhad. 2015. Comparative Advantage in Smith's Wealth of Nations and Ricardo's Principles. History of Economic Ideas, XXIII (1): 59-75.

Ricardo, David (1951-1973). The Works and Correspondence of David Ricardo, edited by Piero Sraffa with the collaboration of M. H. Dobb. Cambridge: Cambridge University Press.

Robbins, Lionel. 1958. Robert Torrens and the Evolution of Classical Economics. London: Macmillan.

Rodrik, Dani. 1998. Symposium on Globalization in Perspective: An Introduction. Journal of Economic Perspectives, 12 (4): 3-8.

Rothbard, Murray N. 1996. Classical Economics: An Austrian Perspective on the History of Economic Thought, Volume II. Cheltenham (U.K.): Edward Elgar.

Ruffin, Roy J. 2002. David Ricardo's Discovery of Comparative Advantage. History of Political Economy, 34 (4): 727-748.

Ruffin, Roy J. 2005. Debunking a Myth: Torrens on Comparative Advantage. History of Political Economy, 37 (4): 711-722.

Ruffin, Roy J. 2017. Ricardo an international trade theory. In Ricardo and International Trade, eds. Senga, Shigeyoshi, Masatomi Fujimoto, and Taichi Tabuchi. London: Routledge, pp 20-32.

Schonhardt-Bailey, Cheryl. 2006. From Corn Laws to Free Trade: Interests, Ideas, and Institutions in Historical Perspective. Cambridge, Mass.: The MIT Press.

Seligman, Edwin R. 1903. On Some Neglected British Economists. The Economic Journal, 13 (51): 335-363.

Seligman, Edwin R. 1911. Ricardo and Torrens. The Economic Journal, 21 (83): 448-455.

Senga, Shigeyoshi, Masatomi Fujimoto, and Taichi Tabuchi, eds. 2017. Ricardo and International Trade. London: Routledge.

Smith, Adam. [1776] 1976. An Inquiry into the Nature and Causes of the Wealth of Nations. Indianapolis: Liberty Fund. 
Sraffa, Piero. 1930. An Alleged Correction of Ricardo. The Quarterly Journal of Economics, 44 (3): 539-544.

Thweatt, William O. 1976. James Mill and the Early Development of Comparative Advantage. History of Political Economy, 8 (2): 207-234.

Torrens, Robert. 2000. Collected Works of Robert Torrens, Vols. I-VIII, ed. Giancarlo de Vivo. Bristol: Thoemmes Press.

Torrens, Robert. 1815. An Essay on the External Corn Trade. London: J. Hatchard.

Torrens, Robert. 1826. An Essay on the External Corn Trade. Third Edition. London: Longman, Rees, Orme, Brown and Green.

Viner, Jacob. 1937. Studies in the Theory of International Trade. London: Allen \& Unwin. 